\title{
An evaluation of the effect of ICT on job characteristics in Kenyan banks: Case of banks in Nakuru town
}

\author{
Ednah Kemunto Nyambega ${ }^{1}$, Richard Bitange Nyaoga ${ }^{2}$, Daniel Ongeri Kerandi ${ }^{1}$ \\ ${ }^{1}$ Faculty of Commerce, Department of Accounting, Finance \& Management Science, Egerton University, Nakuru-Kenya \\ ${ }^{2}$ Lecturer, Faculty of Commerce, Department of Accounting, Finance \& Management Science, Egerton University, Nakuru-Kenya
}

Email address:

eknyambega@gmail.com (E. K. Nyambega),rnyaoga@yahoo.com (R. B. Nyaoga), dankerandi@yahoo.com (D. O. Kerandi)

\section{To cite this article:}

Ednah Kemunto Nyambega, Richard Bitange Nyaoga, Daniel Ongeri Kerandi. An Evaluation of The Effect of ICT on Job Characteristics in Kenyan Banks: Case of Banks in Nakuru Town. Science Journal of Business and Management. Vol. 2, No. 2, 2014, pp. 77-90. doi: $10.11648 /$ j.sjbm.20140202.14

\begin{abstract}
This study sought to evaluate the effect of the ICTs on job characteristics of employees as characterized in the banking sector, case of banks operating in Nakuru- Kenya. The focus of the study was on the effects of ICTs on the five job characteristics namely; skill variety, task identity, task significance, autonomy and feedback, in the job characteristics model (JCM). The study used descriptive survey research design. Data collection was undertaken by use of questionnaires, edited and processed using Statistical Package for Social Sciences for windows version 20.0. Pearson's coefficient of correlation (r) was used to assess the effect of the ICTs on job characteristics. A within subject comparison using ANOVA followed by a Levene's test was conducted to test the mean differences of job characteristics within the employees who reported use of ICTs and those who did not. The findings indicated that use of ICT had significant positive influence on the job characteristics as hypothesized.
\end{abstract}

Keywords: Job Characteristics, Information and Communication Technology (ICT), Banking Sector

\section{Introduction}

Over the past few decades dramatic changes in work contexts have occurred in the economy. These changes include a shift from a manufacturing to a service -oriented economy, an increase in the scope and importance of the knowledge-based industry, and the knowledged workers who are exposed to challenging cognitive demands; an increase in emotional and interpersonal tasks in service work; an increase in the task independence and the use of teams. Significant growth in global operations across different countries, societies and cultures and the growing use of continued breakthrough technology and flexible work methods ranging from virtual teams to telework as a basis for operations. All these changes are associated with increased unpredictability and uncertainty. At the same time; the nature of workforce itself is changing considerably, with more women involved, greater ethnic diversity, more educated employees and altered psychological contracts between employer and employees. These changes give rise to new questions about the nature, effects on design of jobs and principles of a socio-technical workplace that greatly emphasize on the role of technology in a business' success.
By designing work positions around certain technologies, it is possible to optimize their use. This optimization does not simply involve placing the most qualified people in place to use the technology, but in centering their social arrangements on the technology (Muisyo, 2012).

Hackman and Oldham (1975) in their study stated that Job design is a branch of business science that attempts to understand the factors that go into creating a job position and how they might be optimized. Achieving the right kind of fit for the right kind of worker is a vital concern in today's business world, where specialization is more common. In many cases jobs may be designed in such a way that they complement the skill sets of a certain type of optimal worker.

Organizations can encourage positive employee attitude and enhanced quality of work by enriching a job along five job design characteristics; skill variety, task identity, task significance, task autonomy and feedback. Skill variety is the degree to which a job requires a variety of challenging skills and abilities, task identity is the degree to which a job requires completion of a whole and identifiable piece of work, task significance is the degree to which a job has a perceived freedom and independent in scheduling work 
and determining how the work will be carried out; and feedback is the degree to which a worker gets information about the of his or her efforts either direct from the work itself or from others.

Hackman and Oldham (1980) in their study argued that these core job design characteristics influence three critical psychological states; experienced meaningfulness of work, experienced responsibilities for work outcomes, and knowledge of the results that in turn, influence affective personal work outcome; high internal work motivation, high growth job satisfaction, high general job satisfaction, high work effectiveness and low absenteeism rates. A large body of research provides evidence that the way jobs are designed impacts outcomes that are important to workers (job satisfaction) and to employers (productivity). Job design can be approached with one or more goals in mind. For instance, jobs can be designed in the interest of increasing production efficiency, minimizing physical strain, or with an eye on maximizing the extent to which they are motivating to the worker (Campion and Thayer, 1985).

Joseph \& Stone, (2003) in their study stated that the history of technology is history of invention of tools and techniques. The $19^{\text {th }}$ century witnessed developments in communication technology originating in Europe. Due to the scientific gains directly tied to military research and development in $20^{\text {th }}$ century information technology developed rapidly. Despite the fact that the $21^{\text {st }}$ Century has just started, technology is being developed even more rapidly, marked progress in almost all fields of Science and Technology has led to massive improvement to the technology used currently. IT also known as ICT is a term that describes the combination of computer technology which is hardware and a software telecommunication technology such as data, image and voice networks.

Kenston and Kumar, (2004) in their study asserted that massive and rapid technological innovation are replacing the traditional branch teller with greater competition brought by deregulation, globalization and widespread mergers and acquisition taking place in the banking facilities like the ATM as part of a larger rationalization exercise; 'Even with the massive branch network, the use of phone banking and internet banking is strongly promoted by the banks in addition to ATMs.'

Kenston and Kumar, (2004) in their study noted that in today's banking environment, information technology, effective service delivery and customer satisfaction are an indispensable competitive strategy. Furthermore, the stiff competition and the compression of the interest rates, has forced banks to set up and put into effect all necessary decision support technological systems.

The development in ICT is radically changing the way business is done. Electronic commerce is now thought to hold the promise of new commercial revolution by offering an inexpensive and direct way to exchange information and sell or buy products and services. This revolution in the market place has set in motion a revolution in the banking sector for the provision of a payment system that is compatible with the demands of the electronic market place (Abor, 2005). Researches have been done in areas of service excellence and customer satisfaction in the banking industry but little has been done on the impact of technological innovation in Commercial banks in Kenya with reference to employees job characteristics and outcome, and therefore this study seeks to evaluate the effect of technological innovation on employees' jobs characteristics and job outcome in commercial banks in Kenya.

\subsection{Banking Industry in Kenya}

Muisyo, (2012) in his study asserted that Kenya's banking sector is a cut-throat business arena, with 44 players by August 2012, including Multinationals all scrambling for a slice of the pie. Out of the 44 , one is a mortgage financial institution; Housing Finance Ltd and 43 are bank financial institutions. Out of the 43, 23 are locally owned, 5 are foreign owned, 9 are foreign partly owned locally and 6 banks have significant government participation.

The banking industry in Kenya is governed by the companies Act, the Banking Act, the Central Bank of Kenya Act and the various prudential guidelines issued by the Central Bank of Kenya. The banking sector was liberalized in 1995 and exchange controls lifted (Okatch, 2009). Banking can be traced back to the year 1694 with the establishment of the bank of England. The bank was started by a few individuals who were actually money lenders with an aim of lending money at an interest. The banking industry in Kenya started in 1896 with the National Bank of India opening its first branch. Standard Chartered Bank opened its first branches in Mombasa and Nairobi in January 1911.The Kenya Commercial Bank was established in 1958 with Grindlays Bank of Britain merging with the National Bank of India. The Cooperative Bank of Kenya was established in 1965 for the express purpose of providing financial services to Cooperative societies. Three years later, National Bank of Kenya (NBK) was incorporated (Ojung'a, 2005). Over the last few years, the banking Sector in Kenya has continued to grow in assets, deposits, profitability and product offering. This growth has been mainly due to automation of a large number of service and a move towards emphasis on the complex customer needs rather than traditional off-the-shelf banking products (PWC, 2012).

\subsection{Statement of the Problem}

Technology has really revolutionized the banking system in the world Kenya inclusive. Such is the pace of technology advancement that self-service banking is a reality. Increasingly, banks are operating in an intensely competitive financial market with Millions of shillings being spent annually on ICT implementation in Kenya. Such ICT implementations play an important role in fostering socioeconomic development. In particular, ICTs have been a key building block in bringing better quality of life, education, health care and government. There is a rich body of literature that has investigated the impact of ICTs on the 
performance of organizations in general and service organizations in particular. Notwithstanding the vast body of research in these areas, there was need of research on the impact of ICTs on employees' jobs and job outcome in developing countries, particularly in the service sector. Developing countries have unique socioeconomic, cultural and regulatory conditions yet they are implementing complex, enterprise-level ICTs, in response to highly competitive and dynamic business environments. It is not clear how these technologies developed primarily to support the service processes of organizations in developed countries, affect employees' jobs in developing countries, particularly Africa. Therefore from this perspective, there is need to understand the impact of ICTs on employees' jobs in banks, particularly in Kenya from an operations management perspective. This study therefore seeks to evaluate the effect of technological innovation on employees' jobs characteristics and job outcome as characterized in commercial banks in Kenya.

\subsection{Objectives of the Study}

The general objective of this study was to evaluate the effect of ICT on the job design characteristics in Kenyan banks; case of banks in Nakuru town. The specific objectives were: To establish the ICT used by banks in Nakuru town and; To determine the effect of ICT on job characteristics of employees in banks in Nakuru town

\subsection{Justification of the Study}

There are many benefits of ICT in banking, which include; easy access to money. Banks can handle more customers, less staff employed by banks; payment by credit/debit cards so no need to carry money around. The findings of the study would particularly be useful to the policy makers in policy formulation in their endeavor to providing quality banking services through enhancement and empowerment of bank workers in their job characteristics. It could also assist key decision makers and facilitators to match their plans with environmental changes. To bank managers the study would provide insight on how managers can meet needs of today's workers who desire the workplace to be exciting and full of fun. Bank management could adopt the recommendations to develop practices that meet both the needs of employees and those of the organization. Lastly this study to will provide knowledge which would enhance teaching and future research in the area of job design and ICT use.

\subsection{Scope and Limitation of the Study}

This study was limited to effect of ICT on only five job characteristics namely; skill variety, task identity, task significance, autonomy and feedback. The study determined the various ICTs used in Nakuru banks, the effect of these on job characteristics; carried out within Nakuru town and the target sample was the employees of banks operating in Nakuru town. The study was operating under the assumption that the target group provided all the required information concerning the study objectives. However, this study may have been hindered by the difficulty in obtaining information from the staff since they were bound by the policy of secrecy. Due to the secrecy policy affecting accessibility of bank staff, the respondents were assured of confidentiality of any information they gave.

\section{Literature Review}

\subsection{ICT Tools Used in Banks}

According to Laudon and Laudon (2001), Communication Technology deals with the physical devices and software that link various computer hardware components and transfer data from one physical location to another. ICT products in use in the banking industry include: Automated Teller Machine, Smart Cards, Telephone Banking, MICR, Electronic Funds Transfer, Electronic Data Interchange, Electronic Home and Office Banking.

Coombs et al, (1987) defined IT as the modern handling of information by electronic means, which involves its access, storage, processing, transportation or transfer and delivery. According to Agboola (2007), IT affects financial institutions by easing enquiry, saving time and improving service delivery. In recent decades, investment in IT by banks has served to streamline operations, improve competitiveness and increase the variety and quality of service provided.

Fisher, (1998) argued that technology when applied in today's banking environment falls into three specific categories; firstly, Customer independent (a technology that involves a customer conducting and completing a transaction with a bank entirely independent of any human contact with the institution, for example ATMs, phone banking and internet banking. Secondly, customer assisteda bank employee will use customer - assisted technology as a resource to complete a transaction for example call centers customer service officers will use a CRM system to understand a customer's profile and provide instant responses to customers queries on the banking transactions and up-to-date billings and Lastly; customer transparent; customer technology which represents the real core of bank operations and customers never see it but expect it.

\subsubsection{Automated Teller Machines (ATMs)}

According to McGill (2003), an automated teller machine (ATM) is a computerized telecommunications device that provides the customer of a financial institution with access to financial transactions in a public space without the need for a human clerk or bank teller. ATMs are known by various casual terms including automated banking machines, money machines, bank machines, cash machines, hole-in -the -wall and cash point.

Lockett and Littler, (1997) in their study stated that ATMs typically connect directly to their ATM controller via either a dial-up modem over a telephone line or directly via a leased line. Blake (2000), in her study asserted that, on most 
modern ATMs, the customer is identified by inserting a plastic ATM card with a magnetic stripe or a plastic smartcard with a chip which contains a unique card number and some security information such as a expiration date. Security is provided by the customer entering a personal identification number (PIN).

ATMs are placed not only near or inside the banks premises, but also in locations such as shopping centre, malls, airports, grocery stores, petrol stations, restaurants or any place where large numbers of people may gather as observed by Davies (1990). Moutinho and Curry, (1996) in their study stated that ATMs are the most frequently used electronic distribution channel that allows bank clients to perform their main banking transactions such as access their bank accounts in order to make cash deposits and withdrawals 24 hours a day. Most ATMs are connected to interbank networks, enabling people to withdraw and deposit money from machines not belonging to the bank where they have their account or in the country where their accounts are held thus enabling cash withdrawal in local currency (Maxwell, 1990). In some cases, fees are charged solely to users who are not customers of the bank where the ATM is installed, in other cases they apply to all users (Lustsik, 2003).

ATMs were introduced first to function as cash dispensing machines. However due to advancements in technology, ATMs are able to provide a wide range of services, such as making deposits, funds transfer between two or more accounts and bill payment (Rose,1999).

\subsubsection{Telephone Banking}

According to Cronin, (1997) telephone banking is a service provided by a financial institution which allows its customers to perform by telephone. Mostly telephone banking uses an automated phone answering system with phone keypads response or voice recognition capacity. To guarantee security, the customers must first authenticate through numeric or verbal password or through security questions asked by a live representative located in a call centre or a branch, although this feature is not guaranteed to be 24/7. Wisley, (1997) argued out that, telephone banking representatives are usually trained to do what was traditionally available only at the bank such as loan application, investment purchases and redemptions, cheque book orders, debit card replacement and change of address. Telephone banking provides services such as account balance and list of latest transactions transfer of funds between a customer's accounts, electronic for instructions to issue bank cheques (Daries, Moutinho \& Curry 1996).

\subsubsection{Personal Computer Banking}

PC- Banking is a service which allows the bank's customers to access information about their accounts via a proprietary network, usually with the help of proprietary software installed on their personal computer. Once access is gained, the customer can perform a lot of importance of computer literacy has resulted in increasing the use of personal computers (Abor, 2005).

\subsubsection{Internet Banking}

The idea of internet banking according to Essinger (1999) is to give customers access to their bank accounts via a web site and to enable them to enact certain transactions on their account, given compliance with stringent security checks. Internet Banking Handbook (2001) describes Internet Banking as "the provision of traditional (banking) services over the internet".

\subsubsection{Branch Networking}

Networking of branches is the computerization and inter-connecting of geographically scattered stand-alone bank branches into one unified system in the form of a WAN or EN for the creating and sharing of consolidated customer information /records (Abor, 2005).

\subsubsection{Electronic Funds Transfer and Point of Sale (EFTPOS)}

AN Electronic Funds Transfer at the point of sale is an on-line system that allows customers to transfer funds instantaneously from their bank accounts to merchant accounts when making purchases (at point of sale-APOS). A POS uses a debit card to activate an Electronic Fund Transfer process (Chorafas, 1988)

\subsection{Job Design Characteristics}

Hackman et al, (1980) developed a job design characteristics approach to job enrichment. The model is based on the assumption that jobs can be designed not only to help workers get enjoyment from their jobs but also to help workers feel that they are doing meaningful and valuable work. Specifically, the model identifies five core job characteristics that help create three critical psychological states, leading, in turn, to several personal and work outcomes. The job characteristic model is based on the idea that the task itself is key to employee motivation. Specifically, a boring and monotonous job stifles motivation to perform well, whereas a challenging job enhances motivation, variety, autonomy and decision authority are three ways of adding challenge to a job.

There are five core job characteristics namely; skill variety, task identity, task significance, autonomy and feedback, which impact three critical psychological states:-experienced meaningfulness, experienced responsibility for outcomes and knowledge of the actual results. In turn influencing work outcomes (job satisfaction, absenteeism and work motivation). Work must possess some inherent purpose or provide value to its incumbent; a salary or reward, a feeling of achievement or prestige, or perhaps something more meaningful. In recent years, more people are choosing to search for meaning at work than in any other domain of life (Holbeche \& Springett, 2004). Considering most adults spend nearly half of their waking lives at work, this is not surprising (Wrzesniewski, 2003)

Bessette, (2003) and Treadgold, (1999) in their study argued that individuals derived value from their work through spirituality or an inner guidance, while Kristensen 
and associates' (2005) conceptualization of meaningful work indicated that value stemmed primarily from characteristics of the job and how one's work is organized. Bakker \& Demerouti, (2007) concluded that when employees lack autonomy, they may not be equipped to meet the demands that are placed upon them. Furthermore, depending on an individual's work goals, autonomy may be a necessary resource to achieve these goals. Skill variety, task identity and task significance are all job characteristics that stimulate personal growth and development and can help employees achieve their work goals. When employees are given the opportunity to maximize the use of their talent and ability for pursuing a clearly identifiable and worthy outcome or goal, they are more likely to consider their job as one that helps them meet their own personal goals and aspirations. If the aforementioned job characteristics are considered to be job resources, their presence should reduce burnout (Hackman, et al., 1975).

\subsubsection{Skill Variety}

This is the degree to which a job requires a variety of different activities and involves the use of a number of different skills and talents of the employee. Using only one skill to do the same task repeatedly can be quite boring causing the employees productivity to decrease. Jobs that are high in skill variety are seen by employees, as more challenging because of the range of skills involved, relieve monotony that results from repetitive activity, and gives employees a greater sense of competence.

Variety of skills alleviate boredom and foster greater meaning in work by allowing one to express more aspects of his/her personally in her /his work. Skill variety allows the employee to structure the tasks according to his/her own optimal work patterns and provide an opportunity to take on skills to greater complexity in their current roles (Hackman et al, 1975).

\subsubsection{Task Identity}

This is the degree to which a job requires completion of a "whole" and identifiable piece of work, doing a job from beginning to end and with a visible outcome. When employees work on a small part of the whole, they are able to identify any finished product with their effort. Having the opportunity to see a tangible result from one's work can serve as a means of professional self assessment. One is able to see that each step of the task was completed and nothing was left or skipped over.

It also involves broadening of tasks to produce a whole product or an identifiable part of it. They cannot feel any sense of completion or responsibility for the whole product. However, when tasks are broadened to produce a whole product or an identifiable part of it, then task identity has been established. For example, dress designers will have high task identity if they do everything related to making the whole dress; measuring the client, selecting the fabric, cutting and sewing the dress, and altering it to fit the customer, (Hackman et al, 1975).

\subsubsection{Task Significance}

This is the degree to which the job has a substantial impact on the lives of other people, whether those people are in the immediate organization or in the external environment (Hackman et al, 1975). It involves highlighting the contribution of employees' efforts to the welfare of others. Makes employees to believe they are doing something important to the organization or society or both or even the work of others. Employees experience their work as more purposeful and valuable, thus motivating them to invest additional time and energy in completing their assigned tasks.

Even more modest contributions to an organization can be recognized as being important to the extent that employees understand the role of their jobs to the overall mission of the company. The point is that employees should believe they are doing something important in their organization or society, or both.

\subsubsection{Autonomy}

Autonomy is the degree to which the job provides substantial freedom, independence, and discretion to the individual in scheduling the work and in determining the procedures to be used in doing the work. It is considered fundamental in building a sense of responsibility in employees.

Although most employees are willing to work within the broad constraints of an organization, employees want a certain degree of freedom. Autonomy has become very important to people in the workplace. For example, a salesperson is considered to be highly autonomous by scheduling his or her own work day and deciding on the most effective approach to use for each customer without supervision. High motivation is related to experiencing three psychological states whilst working (Hackman et al, 1975).

\subsubsection{Feedback}

This is the degree to which carrying out the work activities required by the job provides the individual with direction and clear information about the effectiveness of his/her performance. It can be positive or negative. Feedback should occur frequently rather than to be delayed until the annual evaluation meeting.

It provides the workers knowledge on how successful their work has been intern enabling them to learn from mistakes. Connect workers with their work emotionally. This helps a person to improve himself to learn new skills to rectify his mistakes so it is not repeated in the future, provides solution to the problem and builds relationships between managers and employees. Feedback may come from the job itself, from customers, supervisors or coworkers.

\subsubsection{Meaningfulness of Work}

This means that labour has meaning to the worker, something that the worker can relate to, and does not occur just as a set of movement to be repeated. That work is motivating in itself as opposed to motivating only as a means 
to an end. Meaningful work occurs when there is a fit between an employee's personal values and work goals and burnout arises from a misfit between one's intentions and the reality of the job (Schaufeli \&Enzmann, 1998; Spreitzer, 1995). When the characteristics of an employee's job fit with their own values they are more inclined to consider their work to be meaningful. However, when there is a mismatch because of a lack of job resources (or an excess of demands), the lack of meaning is likely to be replaced by feelings of exhaustion, cynicism and reduced professional efficacy. A review of research on the JCM by Fried and Ferris (1987) reported that autonomy was significantly associated with meaningful work. Morin, (2008) concluded that autonomy is a source of meaningful work and Isaksen, (2000) argued that autonomy was one of several mechanisms through which individuals found meaning in their work. Consequently, it is expected that skill variety, task identity, task significance, and autonomy will be significantly related to meaningful work.

\subsubsection{Responsibility}

This means that the worker has been given the opportunity to be a success or failure at his or her job because sufficient freedom of action has been given. This would include the ability to make changes and incorporate the learning he or she has gained whilst doing the job. Responsibility is derived from autonomy, as in the job provides substantial freedom, independence and discretion to the individual in scheduling the work and in determining the procedures to be used in carrying it out. Morgeson and Humphrey (2006) argued out that employees' experience and abilities to carry out their job are heavily influenced by their access to manager's support.

\subsubsection{Knowledge of Outcomes}

This is important for two reasons; firstly, to provide the worker knowledge on how successful their work has been which in turn enables them to learn from mistakes. Secondly, is to connect them emotionally to the work. It implies that an employee awareness of how effective he/she is converting his/her effort into performance and this comes from feedback. This can be anything from production figures through the customer satisfaction scores (Hackman et al, 1975).

Feedback can come from other people or the job itself. This is derived from skill variety, task identity and task significance. Skill variety involves using an appropriate variety of your skills and talents; too many might be overwhelming and too few, boring. Task identity is being able to identify with the work at hand as more whole and complete and hence enabling more pride to be taken in the outcome of that work. Task significance is being able to identify the task as contributing to something wider, to society or a group over and beyond the self. Adler (1991) argued that systems in which employees reported higher perceptions of skill variety, task significance, autonomy and feedback gives higher levels of satisfaction and internal work satisfaction.

\subsection{Effects of ICT on Job Characteristics}

Morris and Venkatesh (2010) in their study argued that technologies can increase uncertainty in the work environment, particularly if a technology is radically different from those to which employees are accustomed. This in turn, can positively influence some aspects of job characteristics, for example skill variety and task significance as employees will need to develop a variety of skills for handling unpredictable job situations and may perceive their jobs as highly significant.

Boston and Heinen, (1977) developed a Social and Technical System (STS) theory in response to findings that organizations were not attaining expected benefits from new technology implementations. According to Social and Technical System theory, organizations comprise of two sub-systems namely; a social system and a technical system. The social sub-system comprises the structural and human elements, while a technical sub-system includes the technical and tasks that individuals will perform using the ICT. Avqerou et al (2004) argued that technical systems typically seek to maximize task accomplishments, while social systems focus on improving quality of work life.

Molleman and Broekhuis, (2001) argued that organizations and employees benefit the most when the social and technical sub-systems of an ICT are in balance with one another. Balance between these sub-systems involve recognizing that both sub-systems affect one another and by redressing imbalances when it occurs. As the economy continues to grow, banks continue to struggle to keep up with the substantially increased volume of transactions. This creates an imbalance between the sub-systems as the people have greater volume of tasks that they need to perform.

Morris and Venkatesh (2010) asserted that although in the absence of an ICT there is a great deal of interaction with managers (tellers at banks have to constantly interact with managers to get transactions approved) there is little or no systematic feedback to employees about their performance on an ongoing basis (error rate, transaction processing time, customer satisfaction). An ICT will allow the easy creation of reports that will provide greater feedback to tellers on their activities and performance (service time, number of customers served). Also specific customers' satisfaction ratings can be quickly and readily associated with a specific teller, thus providing feedback via error messages and chronographs, which detail how long a process is taking, and fast communication with management through electronic means when an employee either asks for it (in case of a question or problem) or needs it (in the case of outstanding or substandard performance). Therefore, an ICT can provide the means through which balance is restored and bank employees are helped in dealing with the substantial increase in volume of activities.

\subsection{Factors Affecting ICT Use}

According to Hofistede (2003) conservative beliefs and 
norms lead to change being viewed unfavorably in organizations. ICT is seen not as a means for the organization to innovate and be competitive but as a wasteful exercise trying to be like other organizations. The unwillingness to change on the part of the employees, a derivative of conservative social norms that are typical of traditional banks and its employees, intensified due to other problems such as environmental barriers and learning difficulty.

Gupta (2005) asserted that the implementation of a new enterprise-wide ICT is not only a change but also one that offers the possibility of streamlining, business processes that could lead to employee layoffs. Employees worry about being able to use the new ICT well enough to keep their jobs or be able to be promoted in the future.

Lazarus and Foltman (1984) asserted that environmental barriers and learning difficulty represent factors that suggest whether employees feel they have enough control over the work conditions enabled by the new ICT. Environmental barriers are barriers that are external to employees, largely beyond an individual's control that creates a first-degree barrier to successful use of the new ICT to accomplish tasks. The environmental barriers not only hinder employees doing their jobs, but also a source of frustration for them.

According to Gupta (2005) employee valuation is categorized as incentive alignment and future ambiguity. The implementation of a new enterprise-wide ICT is not only a change, but also one that offers the possibility of streamlining business processes that could lead to employee layoffs. Employees worry about being able to use the new ICT well enough to keep their jobs or being able to be promoted in the future.

Hays and Hill (2001), asserted that if the employees are reluctant to use a new ICT and their job outcome are unfavorably affected by the new ICT, it is more likely that their overall service performance and organizational service quality will be affected. Ewan and Kraemer's (2000) argued that deployment of ICT in developing countries must be preceded by investment in other resources (infrastructure, human capital).

Ochieng, (1998) asserted that factors considered important in successful implementation of information systems in commercial banks in Kenya included: Awareness of services and their benefits, perceived risk, quality of infrastructure, demographic characteristics and ICT personnel availability.

Agboola (2007) argued that the period between 1990 and 2005 was characterized by fundamental changes in the content and quality of banking business. The adoption of ICT in banking has improved customer services, facilitates accurate records, provided home and office banking services. The facilitation ensures convenient business hour, prompt and fair attention and enhances faster services. The adoption of ICT improves the bank's image and leads to a wider; faster and more efficient market. It also makes work easier and more interesting, improves the competitive edge of banks, improves relationship with customers and assists in solving basic operational and planning problems.

Surendra \& Wulong, (2004) argued that while ICT is productive on its own, it is more productive in firms that combine high levels of ICT with high levels of organizational change. Firms that combine ICT with organizational changes have a high incidence of innovation. Also they found out that ICT and human capital are complements in the service sectors. Firms that combine high levels of ICT and high levels of worker skills have better firm performance.

Kahya (2007) asserted that there was a substantial relationship between employee performance with both job characteristics and environmental conditions. He concluded that poor workplace conditions and hazards result in decreasing employee performance consisting of worker's ability to solve problems, co-operation with coworkers and creativity.

\section{Methodology of the Study}

This study was aimed at collecting information on the effect of ICT on job characteristics in Kenyan banks: Case of banks in Nakuru town. In order to get these data, the researcher used a questionnaire. This instrument was used to collect information about the respondents' perception on the effect of ICT on job characteristics in Kenyan banks: Case of banks in Nakuru town, measured on a 5 point Likert scale. This type is used to measure perceptions, attitudes, values and behavior (Mugenda \& Mugenda, 1999). The study used descriptive survey research design. It also utilized an ex-post facto design because such independent variables such as employee's age, experience, qualifications; gender, and other business related factors cannot be manipulated. The target population was 460 members of staff where 94 members were sampled. Only 70 respondents accepted to participate in the survey as shown in the table1 below. Cochran's (1977) correctional formula was used to calculate the final sample size for the number of banks and employees as shown in Equation (1).

$$
n=\frac{\text { no }}{1 \text { no } / \text { pop }}
$$

Where pop $=$ population of employees of banks in Nakuru town (460).

no $=$ Required return sample size according to Cochran's formula $=118$.

$n=$ required return sample size because sample $<5 \%$ of population (Cochran, 1977).

$$
n=\frac{118}{1 \frac{118}{460}}=93.91
$$

The sample size required for bank employees is 93.91(rounded off to 94). From the target population of four hundred and sixty (460) employees, a sample size of 
94 respondents will be randomly selected to participate in the study

Table 1. Study Population.

\begin{tabular}{|c|c|c|c|}
\hline $\begin{array}{l}\text { Type of } \\
\text { Bank }\end{array}$ & Population & $\begin{array}{ll}\text { No. } & \text { of } \\
\text { Employees }\end{array}$ & $\begin{array}{l}\text { Sample } \\
\text { No. }\end{array}$ \\
\hline Large & $\begin{array}{l}25 \text { and } \\
\text { above }\end{array}$ & 176 & $\begin{array}{l}5 \text { banks } x \\
6=30\end{array}$ \\
\hline Middle & $24-15$ & 191 & $\begin{array}{l}8 \text { banks } x \\
4=32\end{array}$ \\
\hline Small & Below 15 & 93 & $\begin{array}{l}11 \text { banks } x \\
3=33\end{array}$ \\
\hline Total & & 460 & 95 \\
\hline
\end{tabular}

The main instrument for data collection was a semi-structured questionnaire. The questioning was based on the theoretical framework developed from the literature. The questionnaire was administered by the researcher through drop and pick to the respondents at their respective places of work. The Statistical Package for Social Sciences computer programme (SPSS) for windows version 20.0 was used to analyze the primary data. Field data was first sorted out to ensure consistency, exhaustiveness and completeness in information expected. The items or variables in the questionnaires were then identified, coded and entered into the SPSS programme. Pearson's coefficient of correlation (r) was used to assess the effect of the ICTs on job characteristics and job outcome. A group means difference test was used to between-subjects comparisons between the employees who reported use of ICTs

\section{Data Analysis, Empirical Results and Interpretation}

\subsection{Extent of ICTs Use by Banks in Nakuru Town}

The first objective of this study was to establish the extent of ICTs use by banks in Nakuru town. From the findings 78.6\% use branch networking, 64.3\% use EFTPoS, 82.9\% use internet banking and $90 \%$ use telephone banking as shown in Table 2.

Table 2. Extent of ICT use by banks in Nakuru town.

\begin{tabular}{lll}
\hline Response & Frequency & Percent \\
\hline Branch networking & 55 & 78.6 \\
EFTPoS & 45 & 64.3 \\
Internet banking & 58 & 82.9 \\
Telephone banking & 63 & 90.0 \\
\hline
\end{tabular}

\subsubsection{Reasons for Not Using ICTS}

The study also sought to determine the various reasons for not using the various ICTs in banks based in Nakuru town.
On the basis of the study findings (Table 3), the following reasons were identified as reasons for not using ICT: Environmental barriers (lack of network and high transaction load), Learning difficulty (lack of on-site support and lack of knowledge), Culture shock (foreign cultural imposition, compatibility with precursor and delays in work process) and Employee valuation (high cost of ICT system).

Table 3. Reasons for not using ICTs.

\begin{tabular}{lllll}
\hline \multicolumn{4}{c}{ Percentage Responses (\%) } & \\
\cline { 2 - 4 } Reasons & $\begin{array}{l}\text { Branch } \\
\text { Network } \\
\text { ing }\end{array}$ & EFTPoS & $\begin{array}{l}\text { Internet } \\
\text { Banking }\end{array}$ & $\begin{array}{l}\text { Teleph } \\
\text { one } \\
\text { Bankin } \\
\text { g }\end{array}$ \\
\hline $\begin{array}{l}\text { Environme } \\
\text { ntal } \\
\text { barriers }\end{array}$ & 0.0 & 0.0 & 0.0 & 0.0 \\
$\begin{array}{l}\text { Learning } \\
\text { difficulty }\end{array}$ & 7.1 & 8.6 & 0.0 & 0.0 \\
$\begin{array}{l}\text { Culture } \\
\text { shock }\end{array}$ & 14.3 & 27.1 & 28.6 & 4.3 \\
$\begin{array}{l}\text { Employee } \\
\text { valuation }\end{array}$ & 0.0 & 0.0 & 0.0 & 0.0 \\
\hline
\end{tabular}

According to the study data (Table 3), about 7.1 and 8.6 percent reported learning difficulty as a reason for not using branch networking and EFTPos respectively. This indicated that lack of knowledge and lack of on-site support to help employees solve system related problems were reasons why some of them did not use these ICTs in performing their work. On the basis of the field responses, a significant proportion of those not using the various ICTs found culture shock a reason: 14.3, 27.1, 28.6 and 4.3 percent attributed culture shock for not using branch networking, EFTPoS, internet banking and telephone banking respectively. This implied that use of ICTs by bank employees in Nakuru town brought about delays in their work process and incompatibility with the precursor and therefore the employees opted not to use them. In addition, the findings singled out environmental barriers and employee valuation as reasons for not using any specific ICT used by banks in Nakuru town.

\subsection{The Effect of ICT on Job Design Characteristics}

\subsubsection{The Effect of ICT on Skill Variety}

Table 4 indicates that the respondents rated all the three statements above average with the mean scores between $\pi=$ 4.18 and $\pi=4.38$ This shows that commercial banks employees rated their job as being high in skill variety, suggesting that their job included a higher variety of different activities, use of a number of different skills and talents.

Table 4. Rating aspects of Skill Variety.

\begin{tabular}{l|l}
\hline Statement Skill variety & Mean \\
\hline Degree to which your job requires use of different activities, talents and skills. & 4.23 \\
Job enlargement to include more duties and responsibilities. & 4.38 \\
Degree to which job requires change in body position and use of different muscles & 4.18 \\
\hline
\end{tabular}


Table 5. Rating aspects of Task Identity

\begin{tabular}{ll}
\hline Statement & Mean \\
\hline Skill Identity & 4.08 \\
Degree to which job allows completion of whole task & 4.08 \\
Degree to which job includes organized consistent and ongoing training & 4.13 \\
Degree to which job allows change from one task to another & 4.11 \\
Degree to which job allows you to understand the linkage between methods, layouts and procedures & \\
\hline
\end{tabular}

\subsubsection{The Effect of ICTs on Task Identity}

Table 5 indicates that the respondents rated all the four statements above average with the mean scores between $\pi=$ 4.08 and $\pi=4$ 4.13This shows that commercial banks employees' job included completion of a whole and identifiable piece of work; it did not include just doing a portion of a job. Therefore they were able to identify any finished product with their effort.

\subsubsection{The Effect of ICTs on Task Significance}

Table 6 indicates that the respondents rated all the six statements above average with the mean scores between $\pi=$ 3.97and $\pi=4.08$. This shows that commercial banks employees believe they are doing something important in their organization or society, or both job, thus suggesting that banks employees experience their work as more purposeful, interesting and valuable.

Table 6. Rating aspects of Task Significance.

\begin{tabular}{ll}
\hline Statement & Mean \\
\hline Skill Significance & 4.08 \\
Degree to which job impacts on the life of others & 3.97 \\
Degree to which job allows performance of managerial tasks & 4.05 \\
Degree to which you are able to teach others your job. & 4.00 \\
Degree to which your job is interesting & 4.05 \\
Degree to which job provides promotion opportunities & 4.03 \\
Degree to which job offers good status in the society & \\
\hline
\end{tabular}

\subsubsection{The Effect of ICTs on Autonomy}

Table 4.7 indicates that the respondents rated all the four statements below average with the mean scores between $\pi=$ 2.44 and $\pi=2.79$ This shows that commercial banks employees perceived their work as having less freedom, independence, and discretion to the individual in scheduling the work and in determining the procedures to be used in doing the work.

Table 7. Rating aspects of Autonomy.

\begin{tabular}{ll}
\hline Statement & Mean \\
\hline Autonomy & 2.49 \\
Degree to which job gives freedom to plan and schedule & 2.68 \\
Degree to which job provides step by step aid throughout the process & 2.79 \\
Degree to which job provides accountability(audit trail) & 2.44 \\
Degree to which your job allow more responsibility and independence & \\
\hline
\end{tabular}

\subsubsection{The Effect of ICTs on Feedback}

Table 8. Rating aspects of Feedback.

\begin{tabular}{ll}
\hline Statement & Mean \\
\hline Feedback \\
$\begin{array}{l}\text { Degree to which job provides a clear, direct and understandable knowledge of performance (sense of } \\
\text { accomplishment) }\end{array}$ \\
\hline
\end{tabular}

\subsection{Hypothesis Testing}

The main objective of this study was to evaluate the effect of ICTs on employees' job characteristics. In order to respond to these objectives, the study tested the hypotheses that:

$\mathrm{H}_{1}$ : There is a significant effect of ICTs used on employee job characteristics in commercial banks within Nakuru town.
In this respect correlation analysis was done to determine the effects of the ICTs on the employees' job characteristics indicators (dependent variables). This was done after testing of normality among the data using use the Shapiro-Wilk test. Pearson's coefficient of correlation (r) was used to assess the effect of the ICTs on job characteristics. Tables 9- 13 present the multivariate correlation between the ICTs used in Nakuru banks and the measurable indicators of job 
characteristics and job outcome.

Table 9. ICT and employees' skill variety.

\begin{tabular}{lll}
\hline & & Employee skill variety score \\
\hline \multirow{2}{*}{ Branch networking index score } & Pearson Correlation & $.374^{*}$ \\
& Sig. (2-tailed) & .001 \\
EFTPoS index score & Pearson Correlation & $.082^{*}$ \\
Internet banking index score & Sig. (2-tailed) & .004 \\
& Pearson Correlation & $.087^{*}$ \\
Telephone banking index score & Sig. (2-tailed) & .042 \\
\hline
\end{tabular}

$\mathrm{N}=70$

*. Correlation is significant at the 0.05 level (2-tailed).

From Table 9, it is observed that there was a significant positive correlation between the ICT and employees' skill variety at $\mathrm{p}<0.05$, Significance level (2-tailed test). With branch networking $(\mathrm{r}=0.374$ and $\mathrm{p}=0.001)$ EFTPoS $(\mathrm{r}=$ 0.082 and $p=0.004)$,internet banking $(r=0.087$ and $p=0.042)$ and telephone banking $(\mathrm{r}=0.210$ and $\mathrm{p}=0.037)$. This shows that an increased use of these ICTs leads to an increase in skill variety. Suggesting that the greater the extent of use of these ICT by bank employees, the higher the level their job skill variety. The employees that used more of these ICT were more likely to have higher skill variety, and vice versa. This affirms Steers and Porter (1991) proposition that technology tends to stimulate job enlargement, defined as the increasing scope of a job through extending the range of job duties and responsibilities. This is also in agreement with Keniston and Kumar (2004) that ICT automate some aspects of a bank teller's work processes and simplify the workflow, but at the same time, reduce the amount of specialization needed for each teller, instead allowing them to become responsible for many new customer-facing transactions

\subsubsection{Extent of ICTs Use by Banks in Nakuru town}

From the findings $78.6 \%$ use branch networking, $64.3 \%$ use EFTPoS, 82.9\% use internet banking and 90\% use telephone banking as shown in table 2 . This implied that the use of ICTs in Nakuru banks is fairly high.

\subsubsection{Reasons for Not Using ICTs}

From the findings 7.1 and 8.6 percent reported learning difficulty as a reason for not using branch networking and EFTPos respectively. This indicated that lack of knowledge and lack of on-site support to help employees solve system related problems were reasons why some of them opted not to use these ICTs in performing their work.14.3, 27.1, 28.6 and 4.3 percent attributed culture shock for not using branch networking, EFTPoS, internet banking and telephone banking respectively. This implied that use of ICTs by bank employees in Nakuru town brought about delays in their work process and incompatibility with the precursor and therefore the employees opted not to use them. In addition, the findings singled out environmental barriers and employee valuation as reasons for not using any specific ICT used by banks in Nakuru town.

\subsubsection{The Effect of ICT on Job Design Characteristics}

\subsubsection{The Effect of ICT on Skill Variety}

The correlation analysis indicated that there was a significant positive correlation between the ICT and employees' skill variety at $\mathrm{p}<0.05$, Significance level (2-tailed test). With branch networking $(\mathrm{r}=0.374$ and $\mathrm{p}=$ 0.001) EFTPoS $(r=0.082$ and $\mathrm{p}=0.004)$, internet banking $(\mathrm{r}=$ 0.087 and $\mathrm{p}=0.042)$ and telephone banking $(\mathrm{r}=0.210$ and $\mathrm{p}=$ 0.037 ) as shown in the table below.

Suggesting that the greater the extent of use of these ICT by banks employees, the higher the level their job skill variety. To test the mean differences of skill variety within the employees who reported use of ICTs and those who did not, a within subject comparison using ANOVA followed by a Levene's test was conducted. The ANOVA showed ( $\mathrm{F}=$ 1.521 and $\mathrm{P}<0.005)$, at $5 \%$ level of significance, indicating difference in means was significant in scores for only branch networking users and non users. This clearly indicates that Branch networking affects skill variety, and that branch networking is useful as a predictor of employees' skill variety. This was in line with Keniston and Kumar (2004) who argued that ICT automate some aspects of a bank teller's work processes and simplify the workflow, but at the same time, reduce the amount of specialization needed for each teller, instead allowing them to become responsible for many new customer-facing transactions and increase the scope of banking practices with which a teller must be familiar, thus increasing the teller's skill variety.

\subsubsection{The Effect of ICT on Task Identity}

A significant weak positive correlation between the ICT and employees' task identity at $\mathrm{p}<0.05$, Significance level (2-tailed test).With branch networking $(\mathrm{r}=0.026$ and $\mathrm{p}=$ $0.040)$, EFTPoS (0.058 and $\mathrm{p}=0.035)$, internet banking $(0.097$ and $p=0.022)$ and telephone banking $(r=0.029$ and $\mathrm{p}=0.003$.This shows that an increased use of these ICTs leads to a slight increase in task identity. The ANOVA test showed, at 5\% level of significance. This indicated difference in means was significant in scores for branch networking users and non users only. Implying Branch networking affects task identity and that branch networking 
is useful as a predictor of employees' task identity. This affirmed Holman et al (2005) suggestion that ICT tend to allow users a wider compass in terms of business processes due to the automation provided by the ICTs. Also supported Morgeson and Campion (2003) that when parts of a job are automated, employees are freed up to participate in new areas of the business process.

\subsubsection{The Effect of ICT on Task Significance}

From the findings it was observed that there was a significant positive correlation between the ICT and employees' perception of their task significance at $\mathrm{p}<0.05$, Significance level (2-tailed test).With branch networking, $(r$ $=0.121$ and $\mathrm{p}=0.046)$, EFTPoS, $(\mathrm{r}=0.352$ and $\mathrm{p}=0.003)$, internet banking $(\mathrm{r}=0.156$ and $\mathrm{p}=0.048)$ and telephone banking $(r=0.116$ and $\mathrm{p}=0.035)$ as indicated in the table below.

Table 10. Correlation between ICTs and Task Significance.

\begin{tabular}{|c|c|c|}
\hline & & $\begin{array}{l}\text { Employee task } \\
\text { significance score }\end{array}$ \\
\hline \multirow{2}{*}{$\begin{array}{l}\text { Branch networking } \\
\text { index score }\end{array}$} & Pearson & $.121 *$ \\
\hline & Sig. (2-tailed) & .046 \\
\hline \multirow{3}{*}{ EFTPoS index score } & Pearson & $352 *$ \\
\hline & Correlation & $.352^{*}$ \\
\hline & Sig. (2-tailed) & .003 \\
\hline \multirow{4}{*}{$\begin{array}{l}\text { Internet banking index } \\
\text { score }\end{array}$} & Pearson & $156 *$ \\
\hline & Correlation & \\
\hline & Sig. (2-tailed) & .048 \\
\hline & Pearson & $.116^{*}$ \\
\hline \multirow{2}{*}{$\begin{array}{l}\text { Telephone banking } \\
\text { index score }\end{array}$} & Correlation & \\
\hline & Sig.(2-tailed) & .035 \\
\hline
\end{tabular}

This shows that an increased use of these ICTs leads to an increase in employees' perception of their job significance. In the ANOVA test there was significant difference in scores of task significance for EFTPoS users and non users. With $(\mathrm{F}=3.964$ and $\mathrm{p}<0.05)$ at $5 \%$ level of significance. Implying use of EFTPoS affects employees' perception of their work significance, and those EFTPOs are useful as a predictor of employees' task significance. This was in agreement with Campion et al (2005) that ICT positively influences task significance through the mechanism of job enrichment. This occurs when an employee's job is expanded to include higher degree of responsibility and authority.

\subsubsection{The Effect of ICT on Autonomy}

A group means difference test was used to test between-subjects comparisons between the employees who reported use of ICTs (branch networking, EFTPoS, internet banking and telephone banking) and those who did not. To test the mean differences of job characteristics and job outcome within the employees who reported use of ICTs and those who did not, a within subject comparison using ANOVA followed by a Levene's test was conducted. The study showed a significant weak positive correlation between branch networking ,EFTPoS and employees' autonomy at $\mathrm{p}<0.05$, Significance level (2-tailed test) and a weak positive correlation with internet banking telephone banking that was not significant at $\mathrm{p}<0.05$, Significance level (2-tailed test).With branch networking $(\mathrm{r}=0.014$ and $\mathrm{p}=0.000), \quad$ EFTPoS $(\mathrm{r}=0.180$ and $\mathrm{p}=0.002)$, internet banking $(r=0.159$ and $p=0.090)$ and telephone banking $(r$ $=0.147$ and $\mathrm{p}=0.074$ ) as shown in the table below.

Table 11. Correlation between ICTs and Autonomy.

\begin{tabular}{lll}
\hline & & $\begin{array}{l}\text { Employee autonomy } \\
\text { scorel }\end{array}$ \\
\hline $\begin{array}{l}\text { Branch networking } \\
\text { index score }\end{array}$ & $\begin{array}{l}\text { Pearson } \\
\text { Correlation } \\
\text { Sig. (2-tailed) } \\
\text { Pearson }\end{array}$ & $.014^{*}$ \\
EFTPoS index score & $\begin{array}{l}\text { Correlation } \\
\text { Sig. (2-tailed) }\end{array}$ & .000 \\
& $\begin{array}{l}\text { Pearson } \\
\text { Correlation }\end{array}$ & .002 \\
Internet banking index & .159 \\
score & $\begin{array}{l}\text { Sig. (2-tailed) } \\
\text { Pearson } \\
\text { Correlation }\end{array}$ & .090 \\
Telephone banking & Sig.(2-tailed) & .074 \\
index score & & \\
\hline N $=70$ & Correlation is significant at the 0.05 level (2-tailed). \\
\end{tabular}

This shows that an increased use of these ICTs would lead to a slight increase in autonomy. This means that the greater the extent of use of these ICT by banks employees, may lead to a slight increase in employees' perception of their job on provision of substantial freedom, independence, and discretion to the individual in scheduling the work and in determining the procedures to be used in doing the work. The ANOVA tests above showed no significant $\mathrm{F}$ at $5 \%$ level of significance for any of the ICTs. This indicates that the difference in means was not significant in scores for branch networking, EFTPoS, internet banking and telephone banking users and non users. Implying use these four did not affect feedback, and that branch networking and EFTPoS are useful as predictors of employees' autonomy. Therefore, the model is statistically significant in predicting the effect of ICT on employees' autonomy. This shows that there are other factors apart from ICT that affect employees' job autonomy.

\subsubsection{The Effect of ICT on Feedback}

Table 4.13, indicated that there was a significant positive correlation between the ICT and employees' feedback on their job at $\mathrm{p}<0.05$, Significance level (2-tailed test). With branch networking $(0.362$ and $\mathrm{p}=0.002)$, EFTPoS $(\mathrm{r}=$ 0.302 and $\mathrm{p}=0.011)$, internet banking $(\mathrm{r}=0.163$ and $\mathrm{p}=$ $0.046)$ and telephone banking $(r=0.031$ and $p=0.019)$.This shows that the greater the extent of use of these ICT by banks employees, the higher the level of their job feedback. Suggesting that an increased use of these ICTs leads to an increased direction and clear information about the effectiveness of the bank employees' job performance. The ANOVA test showed $(F=11.575$ and $\mathrm{p}<0.05$ and $F=0.033$ 
and $\mathrm{p}<0.05)$ at $5 \%$ level of significance for branch networking and EFTPos respectively as shown in the table below.

Table 12. Correlation between ICTs and Feedback.

\begin{tabular}{|c|c|c|}
\hline & & $\begin{array}{l}\text { Employee feedback } \\
\text { score }\end{array}$ \\
\hline \multirow{2}{*}{$\begin{array}{l}\text { Branch networking index } \\
\text { score }\end{array}$} & $\begin{array}{l}\text { Pearson } \\
\text { Correlation }\end{array}$ & $.362 *$ \\
\hline & Sig. (2-tailed) & .002 \\
\hline \multirow{2}{*}{ EFTPoS index score } & $\begin{array}{l}\text { Pearson } \\
\text { Correlation }\end{array}$ & $.302 *$ \\
\hline & Sig. (2-tailed) & .011 \\
\hline \multirow[t]{2}{*}{$\begin{array}{l}\text { Internet banking index } \\
\text { score }\end{array}$} & $\begin{array}{l}\text { Pearson } \\
\text { Correlation }\end{array}$ & $.163 *$ \\
\hline & $\begin{array}{l}\text { Sig. (2-tailed) } \\
\text { Pearson }\end{array}$ & $\begin{array}{l}.046 \\
.031^{*}\end{array}$ \\
\hline $\begin{array}{l}\text { Telephone banking index } \\
\text { score }\end{array}$ & $\begin{array}{l}\text { Correlation } \\
\text { Sig.(2-tailed) }\end{array}$ & .019 \\
\hline
\end{tabular}

This indicated that the difference in means was significant in scores for branch networking and EFTPoS users and non users only. Implying use of Branch networking and EFTPoS affects feedback, and that branch networking and EFTPoS are useful as predictors of employees' feedback.

This was in agreement with Morris and Venkatesh (2010) assertion that although in the absence of an ICT there is a great deal of interaction with managers (tellers at banks have to constantly interact with managers to get transactions approved) there is little or no systematic feedback to employees about their performance on an ongoing basis (error rate, transaction processing time, customer satisfaction). An ICT will allow the easy creation of reports that will provide greater feedback to tellers on their activities and performance (service time, number of customers served). Also specific customers' satisfaction ratings can be quickly and readily associated with a specific teller, thus providing feedback via error messages and chronographs, which detail how long a process is taking, and fast communication with management through electronic means when an employee either asks for it (in case of a question or problem) or needs it (in the case of outstanding or substandard performance).

\subsection{Conclusion}

Based on the objectives of the study and research results from data analysis and findings of the research, one can safely conclude the following; Firstly, the Nakuru town banks recorded high use of ICTs (branch networking, EFTPoS, Internet banking and Telephone banking) by their employees in performance of their work. This showed that in today's banking environment, information technology is an indispensable competitive strategy. Secondly, the findings suggest that use of ICTs to automate service processes in an organization may be hindered by lack of knowledge and lack of on-site support to help employees solve system related problems were reasons why some of them opted not to use these ICTs in performing their work. Thirdly, the results indicated that the use of ICT had significant positive influence on the job characteristics as hypothesized. Particularly; employees reported a significant positive increase in skill variety, task identity, task significance and feedback with branch networking and EFTPoS. Despite marked increase in skill variety, task identity, task significance and feedback, employees reported a small increase in autonomy which was not statistically significant.

\subsection{Recommendations}

Given the relationship between employees' attitude, behavior and quality of service they provide, if employees are reluctant to use an ICT and their job characteristics are unfavorably affected, it is more likely that their overall service performance and the organizational service quality will be affected. For successful implementation of ICTs in automation of services in an organization, the management should ensure that the contextual barriers such as lack of knowledge, lack of on-site support to help employees solve system related problems, delays in their work process and incompatibility with the precursor barriers are well addressed.

\subsection{Suggestions for Further Studies}

This study provided relevant information on the extent of the use of the ICTs in banks and their effects on employees' skill variety, task identity, task significance and feedback. It is important that further research is carried out to determine other factors affecting employees' job autonomy which was observed to be lower compared to other job characteristics. Also research should be conducted on other job characteristics other than the five from job characteristics model, since there are other job design characteristics that affect employees in their job. This study was conducted on banks within Nakuru town; it is therefore recommended that similar studies be carried out in other economic sectors.

\section{References}

[1] Abor, J.A. (2005). Technological innovators \&Banking in Ghana: An Evaluation of customers Perceptions: university of Ghana, legon.

[2] Agboola, A.A. (2003). Information Technology, Bank automation, and attitude of workers in Nigerian banks. Journal of Social Sciences, 18(3), 234-254.

[3] Avgerou, C, C., Giborra, F. and Land, F. (2004).The social study of information and Communications Technology: Innovation, Actors and context. Oxford University press oxford, UK.

[4] Blake, J. (2000).ATM Security Measures.

[5] Bessett, J.L. (2003).Meaningful Work: A study of Human Resource professionals in Nevada Gaming University of Nevada.
Industry. 
[6] Campion, M.A. et al (2005) work redesign: Eight obstacles and opportunities. Human Resource Management, 44 (4), 367-390.

[7] Campion, M.A. \& Thayer, P.W. (1985. Development \& field evaluation of an interdisciplinary measure of job design. Journal of applied psychology.70, 20-39.

[8] Cochran, W. (1977). Sampling Techniques, 3rd ed. New York: John Wiley \& Sons.

[9] Chorafas, D.N. (1988). Electronic funds transfer, Butterworths, London UK.

[10] Coombs.et al. (1987). Economics and Technology change, Macmillan: London.

[11] Davies, F., Mountinho, L \& Curry, B.(1996).ATM users Attitude: a neutral network analysis; Marketing Intelligence \& Planning. 14(2);26-32.

[12] Essinger, J. (1999).The virtual banking revolution: The customer Bank and the future. International Thomson business press London, UK.

[13] Fisher D.M. et al. (1998). Organizational flexibility and employment dynamics at young \& old Plants; Federal Reserve Bank of Chicago working paper series

[14] Fred, Y. \& Ferns, G.R. (1987). The validity of the job characteristic model: A review \&meta- analysis personnel psychology.40 (2), 287-322.

[15] Gupta, R.K., (2005) India's economic agenda: An interview with Manmshan Quart. (2nd Ed), 122-132.

[16] Hackman, J.R\& Oldham, G.R. (1980).Development of job diagnostic survey. Job application Psychology 60(2):159-170.

[17] Hackman, J.R\& Oldham, G.R. (1975).Development of job diagnostic survey. Job application Psychology 60(2):159-170.

[18] Hays, J. M., A. V. Hill. 2001. A preliminary investigation of the relationships between employee motivation/vision, service learning, and perceived service quality. J. Oper. Manage. 19(3): 330-349.

[19] Hofstede, G. (2003).Culture's consequences company values, Behaviors, Institutions and Organizations across Nations. Sage publications thousand Oaks, CA.

[20] Holbeche, L. \& Springett N. (2004). In search of meaning in the workplace .Honshem Roffer Park.

[21] Internet banking Handbook (2001) Federal Revenue Bond of Chicago's office of the Comptroller of the currency (OCC).

[22] Isaksen, J. (2000).Constructing meaning despite the drudgery of repetitive work. Journal of Humanistic psychology, 40(3):84-107.

[23] Joseph, M. \&Stone, G., (2003). An empirical evaluation of US bank customer perceptions: the Impact of technology on service delivery in the banking sector, international journal of marketing \& distribution Management 31(4):190-202.

[24] Kahya, E. (2007).The effect of job characteristics \& working condition on job performance: Int.j.Ind.Ergon:37; 510-519.

[25] Keniston \& Kumar, K. (2004). IT Experience in India:
Bridging the Digital Divide. Sage Publications, New Delhi, India.

[26] Kristensen, T.S.et al. (2005).The Copenhagen psychosocial questionnaire-a tool for the assessment \& improvement of the psychosocial work environment. Scandinavian Journal of work, environment and health, 31 (6):438-449.

[27] Laudon, D.P. and Laudon, J.P. (2001). Management Information Systems: Organization and Technology in the Network Enterprises, (4th ed). Prentice Hall International in. U.S.

[28] Lazarus, R. S. \& Folkman, S. (1984). Stress, Appraisal, and Coping. Springer, New York.

[29] Lockett, A. \& Litter, D. (1997).The adoption of direct banking services: Journal of Marketing management.13 (8):791-811

[30] Lustsik, O. (2003).E-banking in Estonia: Reasons and Benefits of rapid growth, University of Tartu-Working paper series 21 .

[31] Maxwell (1990).Resolution of Banking Disputes

[32] McGill, J. (2003) 'Communications at the ATM', Touch points, accessed 16 April 2012, from http://www.self-service-touchpoints.com/content.asp?contw $\mathrm{d}=$ web+enabled

[33] Molleman, E. \& Broekhuls, M., 2001) socio-technical systems: Towards an organizational learning approach 18(2):271-293.

[34] Morgenson, F. P\& Campion M. A. (2003). Work design. Springer, New York, NY. Pp423-452

[35] Morin, E.M. (2008).Qu'est-ce qui donne du sens au travl? Objectif prevention, 31(2):10-12

[36] Morris, M. G\& Venkatesh, V. (2010). Enterprise resource planning systems implementation and Organizational change: Impacts on job characteristics and job satisfaction MIS Quart.34 (1):143-161.

[37] Moutinho, L. \& Curry, W. (1996).ATM user attitudes: a neutral network analysis. Marketing Intelligence \& planning, 14(2):26-32.

[38] Ochieng, J.B. (1998).Analysis of Factors Considered Important in the Successful Implementation of Info Systems: A Case Study of Commercial Banks in Kenya. University of Nairobi Unpublished MBA Project.

[39] Ojunga, S. (2005). A survey of E-commerce in commercial Banks in Kenya. Unpublished MBA Research project, University of Nairobi.

[40] Oketch, F.O. (2009).Seminar on trade in service \& investment Kenya banking industry experience on 17/2/2009 at southern Hotel Dar-es-salam Tanzania. Multi lateral Trade export Ht:www.slideshare.net/simandef/Kenya-banking -industry on 9/10/2012.

[41] Rose, P.S. (1999). Commercial Bank Management (4th ed) Lwin /McGraw - Hill, Boston USA.

[42] Schaufeli, W. \& Enzmann, D. (1998).Burnout and occupational stress: psychoanalytic study burnout. Taylor \& of professional Francis publisher 
[43] Spreitzer, G.M. (1995).Psychological empowerment in workplace: Dimensions, Measurement and Validation. Academy of Management Journal, 38(5), 1442-1465.

[44] Steers, R.M. \& Porter L.W. (1991).Motivation and Work Behavior. Sage Publication, New York.NY.34 (6):567-598.

[45] Surendra, G. and G. Wulong, 2004. The Effect of Organizational Innovation and Information Technology on Firm Performance", International Productivity Monitor, No.9
[46] Treadgold, R. (1999).Transcendent vocations: Their relationship to stress, depression and clarity of self-concept. Journal of Humanistic psychology, 39(1), $84-105$

[47] Venkatesh, V., Bala, H. \& Sykes, T.A.(2010).Impact of ICT implementation on employees' job in service organizations in India. Production and Operations Management Journal, 25(4), 591-614.

[48] Wisley, J. (1997).Banking \& Finance on the Internet. 